\title{
Effectiveness of the Big6 Model in Developing Student Teachers' EFL Multimodal Writing Skills
}

\author{
Dr. Hager Gamal Ahmed Labib al-Tonsi*
}

\begin{abstract}
This research sought to determine the effectiveness of a suggested program based on the Big6 Model in developing student teachers' EFL multimodal writing skills. Participants were 100 third year students from the general sector of the English department at a Faculty of Education in Egypt. They were equally divided into an experimental and another control group and the quasi-experimental pretest- posttest design was used. Both groups were pretested, and post tested on the EFL Multimodal Writing Test, scored by two raters according to the rubric developed by the researcher. Participants of the experimental group were taught the suggested program based on the Big6 Model and were asked to write reflection reports describing their learning experiences during the program administration. The statistical analysis of the participants' results on the post administration of the EFL Multimodal Writing Test showed that the experimental group outperformed the control one on the post administration of the test. The Big6 Model based program had a large effect size $(\mathrm{d}=2.24)$ and the experimental group students developed their information search skills as well as their multimodal writing skills.
\end{abstract}

Keywords: Big6 Model, multimodal writing skills, student teachers

\section{Introduction}

University students are expected to construct their own knowledge, search, and process information through meaningful learning experiences (Kicken et al., 2008; Vandergriff, 2016). Mike Eisenberg and Bob Berkowitz in 1990 developed the Big6 Model which refers to the information search processes used to find, apply, and evaluate information for specific tasks. The model can be integrated into different courses to help students complete a task, take a decision, or solve a problem (Swapna\& Biradar,2017). The Big6 Model is used to teach inquiry, information, and research skills. It is easily applied when students need and use

*Assistant professor of Curriculum and Methods of Teaching English, Faculty of Education, Helwan University, Egypt

Email: hagereltonsi2016@gmail.com

Received on: 4 / 5 / 2021 - Accepted for publication on: 5 / 6 /2021- E-published on: 6/2021 
information. Students apply the information search skills to find, use, apply, and evaluate information needed (Marino, 2019).

Multimodal writing is based on information having many forms and different modalities. Students gather, process, and communicate information from different sources to develop their multimodal texts (Foo et al.,2014). Multimodal writing is the final product of integrating two or more modes of representations using digital technologies. The availability of ubiquitous digital tools encourages teachers to tailor multimodal writing tasks to achieve students' learning outcomes besides developing their creativity and engagement (Fjørtoft,2020). Multimodal writing ensures equality since students can use different communication modes instead of the alphabetic mode and can share knowledge in various methods (Shanahan,2012; Wiseman et al.,2017). Multimodal texts engage students in rich authentic learning contexts to achieve different purposes (McConnell,2014).

Though teachers should be able to use technology to design multimodal writing (ISTE, 2016), there is a lack of focus on multimodal writing in teacher education programs (Bailey, 2012). Student teachers do not receive enough instruction on integrating multiple modes in writing (Shanahan, 2012). English syllabuses in K-12 depend on multimodality that is not adequately explained in EFL teacher education programs (Zhang,2020). Such programs focus on the traditional mode of writing, while multimodal writing overcomes the challenges of textual writing (Yeh et al., 2020). EFL teaching should respond to the digital changes through offering different multimodal learning contexts (Ganapathy \& Seetharam, 2016).

University students should be familiar with the Big6 Model, as an information search model, to finish their learning tasks using its steps: task definition, information seeking strategies, information location and access, information use, synthesis, and evaluation (Mendoza et al.,2020). EFL writing requires complicated metacognitive skills (Yeh et al.,2020), and the Big6 Model employs metacognitive skills too (Wolf, 2003). EFL writing requires both linguistic knowledge, such as grammar and vocabulary, and strategic knowledge, such as planning and organization (Aydın \& Y1ldı, 2014). EFL Multimodal writing requires the integration of different modes to express linguistic and strategic knowledge through systematic information search processes.

EFL student teachers should be able to search for information and integrate technology to produce different types of texts whether monomodal or multimodal (NAQAEE, 2013). To the best knowledge of the researcher, there is a paucity of research on using the Big6 Model to develop EFL student teachers' multimodal writing skills.

The researcher developed and administered the multimodal writing test to 20 third year EFL student teachers at Helwan Faculty of Education in May 2019. They were asked to write an electronic multimodal text on "integrating technology in education". Results showed that $73 \%$ of the students did not reach $50 \%$ of the total score of the exam, see scoring rubrics in Appendix C. This can be explained that they focused on developing their academic writing skills in the writing courses taught to them (Writing $1 \&$ Writing 2) during their previous faculty years and did not receive enough teaching on multimodal writing skills. The problem 
could be stated as follows: Third year EFL student teachers at Helwan Faculty of Education have low levels of multimodal writing skills.

Thus, the purpose of this research was to examine the effectiveness of a suggested program based on the Big6 Model in developing EFL student teachers ' multimodal writing skills.

The research tries to answer the following questions:

1-What are the multimodal writing skills appropriate to EFL student teachers at Faculties of Education?

2-What are the components of a suggested program based on the Big6 Model that aims at developing EFL student teachers ' multimodal writing skills?

3- What is the effectiveness of a suggested program based on the Big6 Model in developing EFL student teachers' multimodal writing skills?

The significance of the research could be summarized in the following:

1- Developing the multimodal writing skills of the EFL student teachers at Faculties of Education.

2- Responding to the international and national standards for teacher education programs.

3-Paving the way to further research either on the Big6 model or multimodal

writing skills in light of the findings and recommendations of this

research.

Several delimitations were identified in this research:

1- Participants were delimited to the third year EFL student teachers, from the general section, at Helwan Faculty of Education.

2- The first term of the academic year 2019/2020; from October 9 to December 4, 2019.

3- The following main multimodal writing skills and their sub skills: accurate use of visuals, consistent use of different fonts and colors, appropriate use of formatting and layout, comprehensive content development, accurate reference citation, and

attractive multimodal text production.

The main terms used in this research were defined as follows:

\section{The Big6 Model}

For the purposes of this research, the Big6 Model referred to the steps that enabled EFL student teachers to develop a multimodal text. The steps were task definition, information 
seeking strategies, information location and access, information use, synthesis, and evaluation.

\section{Multimodal Writing Skills}

Multimodal writing skills were the skills targeted by the suggested program based on the Big6 Model. There were six main skills: accurate use of visuals, consistent use of different fonts and colors, appropriate use of formatting and layout, comprehensive content development, accurate reference citation, and attractive multimodal text production. Each main skill included some sub skills, refer to Appendix A.

\section{Review of Literature and Related Studies}

University students should develop their information searching skills to become information literate. Information literacy, suggested by Paul Zurkowski in the 1970s, is the ability to identify the information needed, locate it, and evaluate it in diverse contexts. Students find, process, and apply information in different situations (Probert,2009). Universities should offer great attention to information literacy since it enables students to apply different information search skills to any course (Swapna \& Biradar ,2017). University students suffer from anxiety and disorientation when dealing with online search tasks (Tsai et al.,2012). University instructors should assist their students during their online search since they are not skilled searchers (Zhou \& Lam,2019).

The Big6 Model is widely used in schools and higher education institutions across the world to teach information and technology skills (Aggarwal \& Sarman, 2017; Mendoza et al., 2020). The Big6 Model helps students achieve information literacy skills since they can synthesize, evaluate, and use information to solve problems or complete tasks whether personal or academic (Kumar et al.,2005). It is an instructional methodology used to offer university students the essential skills for lifelong learning. The model offers a learning experience where students integrate information retrieval processes into any subject (Loo \& Chung, 2006).

Shoeb (2020) examined the effect of a training program based on the Big6 Model, as an information literacy model, on students' perceptions towards their research practice. The model was integrated as part of three different courses taught to 128 undergraduate students. Participants received a structured questionnaire before and after the training program. Data analysis of students' answers on the questionnaire revealed that the program enhanced students' perceptions towards their research practice. The model offered an active learning environment in the three courses.

The Big6 Model is an information search model that helps students at different stages to solve any information problem. It offers systematic guidance for students through their online search (Mendoza et al., 2020; Swapna \& Biradar ,2017). Students can handle any problem, assignment, decision, or task by following the Big6 Model steps. The model depends on 
integrating information search with technology tools so that students can locate, use, synthesize, and evaluate information to finish their learning tasks. Students limit their search needs and use information effectively (Mendoza et al., 2020).

Karadeniz(2014) tried to integrate the Big6 Model and project based learning in the Operating Systems and Applications course. Participants were 25 students in the Department of Computer Education and Instructional Technologies in a private university in Turkey. Students' projects were assessed according to these criteria: adopting the Big6 Research Framework (20\%), developing presentation materials according to a set of design principles (15\%), presenting the project using presentation skills (25\%), developing reflection papers (10\%) and writing a project report reflecting the APA Style (30\%). Findings of the study revealed that students were successful in using the Big6 Model through project based learning since the model offered a framework for the project.

Wolf (2003) discusses how The Big6 Model supports Palinscar's (1986) definition of metacognition. The Big6 Model defines information problem solving within information search processes. Metacognition is the ability to plan, implement, and evaluate learning performance. Students who engage in task definition and information seeking are formulating a plan to complete a learning task. In the steps of location and access, use of information, and synthesis, students apply their plans. Evaluating the process and product resulting from the synthesis activity is the final step of both the Big6 Model and metacognitive learning.

The Big6 Model is flexible enough to be applied to any subject area. The information problem solving skills, the steps of the model, encourage students' metacognitive skills (Pórarinsdóttir \& Pálsdóttir,2011). The model is used in instruction as a framework for the metacognitive steps of the information search processes (Nesset, 2014). Metacognition targets higher-order thinking skills, such as planning, regulation, analysis, synthesis, and evaluation which develop the search efficiency (Beal \&Stevens 2011; Cornford, 2005).

Wolf (2003) examined the effect of Big6 as a Metacognitive Scaffold on students' writing skills. Participants were 18 eighth-grade students in a private school in southwestern city in the USA. They were asked to write a news article writing project that included debates, oral presentations, and reports on the events surrounding the African American Civil Right Movement. Students received sessions on the steps of Big6 Model before the writing activity, then they answered a survey after it. Students' projects were scored according to writing rubrics. Students' answers on the survey revealed that they benefited from the Model in writing their projects. It was concluded that the Big6 Model enhanced students' writing skills.

The Big6 Model provides specific search skills that enable students to succeed in any learning context. Students apply the model, without a specific order, as a general framework for dealing with different assignments and tasks (Eisenberg,2008). According to Swapna and Biradar 2017; Brand-Gruwel et al.2009; Chiou et al., Y. .9; Raes et al.,2012, the following is a brief description of the six stages of the Big6 Model. Students may repeat any step and use the sequence appropriate to them. 
First, task definition:

This stage includes defining the task and identifying the information needed. It means identifying the task, posing the questions needed, and limiting the information to be gathered. Students offer outlines to explain their interpretation of the task. Instructors offer scaffolding to activate students' prior knowledge and encourage them to rewrite the task and identify the needed information to answer the questions. In this stage, instructors can use group discussions, chats, videoconferencing, group applications, like blogs or wikis.

Second, information seeking strategies

Instructors offer students different search strategies, such as identifying the search terms in light of the scope and questions of the task and selecting effective keywords. Instructors should discuss the possible keywords before the search. During different search operations, students use new keywords in each search operation to find related information.

Third, location and access

This stage depends on locating the sources considering quality, relevance, and reliability. Instructors guide students while browsing the web pages and help them efficiently use the search time; the information selection depends on the precision of the content in the selected pages according to the search terms. To find relevant and useful sources, students can look at the title and index, identify the aims of the web pages, scan the information using the keywords, and locating the reliable information.

Fourth, use of information:

Students focus on the relevance and accuracy of information included in different sources to determine its usefulness, quality, and correct use. Students evaluate the results critically to identify the reliable sources and suggest how to use the information included in them. They compare information from various sources to answer the questions formulated in the first step. They paraphrase, summarize, and cite sources to avoid plagiarism.

Fifth, synthesis:

In this stage, students organize the information extracted from different sources to present them. They use different techniques of organizing information, such as graphic organizers and mind maps. This stage aims to develop students' ability to complete any learning task by utilizing the content of the searched information that is highly relevant to the search of keywords previously identified. Students combine relevant information from different sources to answer the questions; then, they organize the information to be presented.

Sixth, evaluation:

This stage focuses on judging the effectiveness and efficiency of the information-search process. Efficiency reflects the process of information search, while effectiveness is related to the product. Students evaluate their performance according to the stages of the Big6 Model; 
they judge the quality of their presentations, evaluate whether they find the correct answers to their previously asked questions, and judge their answers. Finally, students offer suggestions to improve the information search process and the quality of their presentations.

As previously discussed, the Big6 Model offers EFL student teachers' the framework to perform their learning tasks efficiently. It can be easily integrated within different learning approaches, like project based learning and metacognitive learning. The steps of the model can be applied, in any order, thoroughly or partially according to the requirements of the learning task. Using the Big6 Model in writing, students form the main question of the writing task, identify the search terms, scan the search results, examine the quality and relevance of the collected information, organize information to be presented, and judge the writing processes and final product.

Multimodal writing was first introduced by the ancient Egyptians who integrated language, gestures, colors, images, as well as other communicative modes in their antiquities. Multimodal writing means integrating multiple ways of communication, and modern technologies enable students to use more than one mode of communication simultaneously (McGrail \& Behizadeh, 2017). Print words are no longer the only means of representation since multimodal texts offer different means (Kress,2003). Multimodal texts exceed alphabets by integrating other forms of expression: images, sounds, or videos (Takayoshi \& Selfe,2007).

Multimodal writing is the integration of different modes to enrich students' writing (Scanlon, 2015). A mode is a social cultural resource used to express meaning (Bezemer \& Kress, 2008). A multimodal context depends on a medium integrated in the written text, such as a poster that includes images and text (Miller-Cochran,2017). Multimodal texts exist in the learning environment either digital or non-digital, like posters, picture books, brochures, PowerPoint slides, and digital stories (Yi, 2017). The learning context includes different modes of representation: print, visual images, and design which convey the social context of learning (Hassett \& Curwood, 2009).

Dzekoe (2013) explored the effect of computer-based multimodal writing activities in developing ESL students' self-revision skill in writing. Participants were 22 ESL students majoring in applied linguistics at Iowa State University. They were unable to define problems with the linguistic and rhetorical features of their drafts. Data were collected through surveying students' revision history and stimulated recall interviews. Results indicated that multimodal writing activities developed the participants' self-revision skill and helped them express their ideas through different modes. The scores of students' final written drafts indicated the quality of their writing.

EFL instructors focus on the teaching strategies that increase students' test scores and such strategies often disengage schools from society. Technology changes how students communicate through different modes. Teaching should satisfy students' learning needs and enable them to be life- long learners, and schools should respond to the changes in societies 
(Ryu \& Boggs,2016). EFL instructors should benefit from students' multimodal experience in their EFL writing (Jiang, 2018).

English instructors often focus on the printed text as textbooks depend on written explanations; in contrast, students deal with pictures, sounds, and different experiences outside classrooms (Gee,2014). EFL textbooks include links to online materials, and the learning situation depends on PowerPoint and images to express meaning. Thus, students deal with different modes of representation: linguistic, auditory, and visual (Kress,2003). Multimodal texts integrate words, images, and audios; whereas digital tools include different modes of communication and students learn better when involved in socially constructed and personal related texts (Albers \& Sanders,2010).

Lee (2014) examined the effect of multimodal writing tasks on students' confidence and motivation. The study adopted two case studies for two years. Participants were two Taiwanese junior college students. The researcher depended on multimodal online literature circles and digital storytelling to offer a series of multimodal writing tasks where students wrote using different modes. The results of the analysis of students' reflection reports revealed that the multimodal learning practices enhanced participants' motivation and confidence.

The types of writing offered to students in formal education are irrelevant to their life. Students depend on printed texts in writing, while they produce multimodal texts through social networks. They integrate images, animations, sounds, graphics, words, and colors in their digital writing spaces (Shepherd,2018; Takayoshi\& Selfe, 2007). Digital texts depend on colors, words, sounds, images, and layouts to enrich the learning context that depends heavily on the linguistic mode (Adami,2016). Digital technologies change students' writing practices; students use different modes of communication to convey their ideas (Huang\& Archer,2017).

Teaching and assessment of writing are monomodal since students are assessed on the skills of producing verbal texts (Cleary,2013; Vincent,2006). Multimodal writing bridges the gap between students' formal and informal writing (Kitalong \& Miner,2017). Multimodal writing enables students to structure relations of meaning between modes and empower their expressions (Nelson,2006). Students should think visually when designing multimodal texts; they integrate different modes of meaning making, such as fonts, colors, and animations (Hung, Chiu\& Yeh,2013).

Ulu et al. (2017) examined the relationship between the multimodal literacy of pre-service teachers and their perception of self-efficacy in critical reading. Participants were 337 preservice student teachers at Hacettepe University. They were from different departments: preschool education, classroom education, and technology education. They were second and third grade students during the academic year 2017-2018.Data were collected through Multimodal Literacy Scale and Critical Reading Self-Efficacy Perception Scale. Results indicated that multimodal had a positive and significant effect on critical reading self-efficacy perception. 
The socio-cognitive learning theory, suggested by Bandura in 1960s, is considered the rationale for multimodality. Multimodality means combining the modes available in a text with those available through the socio-cognitive learning processes. Textual modes may be words, images, or hypertexts; while the socio-cognitive modes include interactions and meaning making of the text within the social context (Hassett \& Curwood,2009). University instructors should update students' writing performance by helping them combine animations, sounds, graphics, words, and colors. Thus, instructors can fill the gap between academic writing and students' daily writing (Takayoshi \& Selfe, 2007).

Zhang (2020) tried to examine the effect of a multimodal vocabulary mini-lesson project on English language teacher candidates' perceptions of designing multimodal teaching materials. Participants were 11 senior candidates enrolled in the Teaching English Language Learners course in the Instructor's Institute in the USA. They were asked to design a multimodal vocabulary mini-lesson project after receiving instruction on multimodality and its different tools. The projects were scored according to a rubric and findings revealed that the multimodal project changed participants' perceptions toward designing multimodal lessons and materials.

The multimodal theory of communication was suggested by Kress and Leeuwen in 2001. It states four assumptions of multimodality: communication is multimodal, a linguistic mode cannot express meaning completely, each mode satisfies specific communicative needs, and different modes integrate to convey meaning. Thus, each mode has a specific role in the meaning making process (Jewitt,2014). The Communicative Language Teaching approach, suggested by Halliday in 1970s, encourages students to use linguistic and nonlinguistic cues in their learning. Multimodality enables instructors to provide a variety of language inputs represented by multiple modes (Ryu\& Boggs,2016). Multimodal writing increases students' awareness of various communicative resources, like images, facial expressions, and gestures (Tan et al.,2016).

Ganapathy and Seetharam (2016) investigated the effectiveness of the multimodal approach on students' meaning making in ESL. Participants were 15 students in a private school in Penang, Malaysia. The study depended on focus group interviews. It was concluded that students achieved the learning outcomes and the multimodal approach enhanced students' learning styles and developed their learning autonomy and motivation.

Teachers need to develop instruments to assess students' multimodal writing. Multimodality is a part of students' life; they communicate through images, sounds, and texts (Vincent,2006). Students facing difficulties in expressing meaning through the linguistic written form can use other alternative forms in writing EFL. English teachers usually focus on students' final writing product instead of the writing process; thus they maintain the traditional mode of writing (Lee,2014).

There is no consistency on how to assess multimodal writing (DePalma \& Alexander, 2015). Instructors can modify the rubrics used to assess alphabetic texts when assessing multimodal writing (Vincent, 2006). The rubrics of multimodal writing cover the integration 
of visual, audio, linguistic, spatial, and structural elements. Visual elements include images, videos, fonts, and colors to support meaning. Audio elements convey the content through audios and voice recordings. Linguistic elements refer to the correct use of words, sentences, and transitions, Spatial elements reflect text arrangement, such as text alignment, image positioning, image size, and text spacing. Structural elements mean accurate punctuation and spelling (Escamilla et al.,2014).

Hafner and Ho (2020) examined the criteria that teachers applied in assessing multimodal compositions and challenges faced during assessment. Participants were 11 teachers who taught English for science course using a process-based model to different departments at a university in Hong Kong. They asked students to produce a digital scientific documentary video uploaded to YouTube. The researchers interviewed the participants who revealed that visual effects, accompanying soundtrack, language use, organization and content were the main criteria for the multimodal composition assessment.

To summarize, multimodal writing is widely neglected in EFL teaching since the assessment of writing depends on its textual form. Multimodality enriches the writing situation and develops student teachers' self-efficacy. EFL student teachers can express their ideas using different communicative modes; visual, textual, or auditory to easily match their future students' learning styles. Multimodality fills the gap between EFL student teachers formal academic writing in campus and their informal writing through social networks.

The Big6 Model reflects EFL writing processes: prewriting, writing, revising, editing, and publishing. The prewriting and writing processes depend on task definition, information seeking strategies, location and access, and use of information. The revising and editing processes benefit from the synthesis step of the model, while the publishing process focuses on the evaluation step. Applying the Big6 Model to the multimodal writing enables EFL student teachers to benefit from different online sources and integrate different mode to express their ideas. They merge linguistic, visual, and spatial modes using different technological tools to express their ideas.

\section{Material and Method}

\section{Research Design}

The research design used in this research was the quasi-experimental pretest- posttest design. There were two equivalent experimental and control groups.

\section{Participants}

Participants were 100 third year student teachers of EFL, from the general section, at a Faculty of Education. They accepted to participate in the study and were distributed equally into a control and experimental groups, 50 students for each group. The Independent samples " $t$ " test $(t=1.475)$ revealed that there was not a statistically significant difference between the mean scores of the control and experimental groups on the pre-administration of the multimodal writing test. 


\section{Instrumentation}

\section{Multimodal Writing Skill Checklist}

The items of the checklist were suggested by related studies and literature previously discussed, such as Albers and Sanders (2010), Jiang (2018), Ryu and Boggs (2016), Wiseman et al. (2017), Shanahan (2012), Lee (2014), and Ganapathy and Seetharam (2016).

\section{Purpose of the Checklist}

The purpose of the checklist was to identify EFL multimodal writing skills appropriate for EFL student teachers at faculties of Education.

\section{Construction of the Checklist}

The initial form of the checklist consisted of four main aspects of multimodal writing skills: linguistic, visual, and spatial skills; in addition to multimodal integration skills. The jury members recommended rearranging the skills in light of the rubric to facilitate the discussion of results. According to the recommendations of the jury members, the checklist was modified in its final form (Appendix A).

\section{Validity of the Checklist}

To examine content validity of the checklist, it was introduced to experts who were gently asked to:

- Determine the multimodal writing skills of EFL suitable for student teachers.

- Suggest any additional skills that need to be included in the checklist.

Experts' recommendations and suggestions were followed, and the checklist was modified in its final version in Appendix (A).

\section{Multimodal Writing Test}

\section{Test Aim}

This test aimed to measure EFL student teachers' multimodal writing skills.

\section{Test Description}

The multimodal writing test included one question: Produce an electronic multimodal text on integrating technology in education. Students were asked to read the test instructions before writing the multimodal text (Appendix B).

\section{Piloting the Test}

The test was piloted on 20 third year English majors at a Faculty of Education in October1,2019 to ensure the clarity of instructions in addition to determining its timing and statistical features. 


\section{Test Timing}

During the pilot administration of the test, the time that each student spent in answering the test was calculated. Then, the total sum of the times was calculated and divided by students' number. The mean of the times of the test items was 120 minutes.

\section{Test Scoring}

The test was scored using the scoring rubric (Appendix C). The total score of the test was 30 divided on 6 main criteria: visuals, fonts and colors, formatting and layout, content development, reference citation, and multimodal text production. The performance rate of each criterion ranged between (1-5). The test was scored by two experts to avoid bias and the mean scores were statistically analyzed.

\section{Test Reliability}

The test was piloted on 20 third year English majors at a Faculty of Education in October 1 ,2019. The reliability of the test was proven through using Cronbach's Alpha. The reliability co-efficient value was (0.646) for the test, an acceptable value.

\section{Test Validity}

The validity of the test was proven through using content validity. It was established by the jury members who were asked to express their opinions regarding:

- Appropriateness of the assigned writing task

- Clarity of instructions

- Accuracy of the scoring rubrics

Following the jury members' recommendations, the test was modified into its final form (Appendix B).

\section{Pre-testing}

The experimental and control groups were assessed by the same test before the administration of the suggested program based on the Big6 Model. It was administered on October2, 2019 to determine students' level concerning the targeted EFL multimodal writing skills.

\section{Post-testing}

The same test was administered on December 5, to examine the effectiveness of the suggested program based on the Big6 Model in developing the participants' EFL multimodal writing skills. 


\section{The suggested program based on the Big6 Model}

Based on the review of literature and related studies, the program was designed. The objectives of the suggested program were as follow:

1-Develop EFL student teachers' multimodal writing skills.

2-Encourage EFL student teachers to integrate multimodal writing skills in their future career.

3-Increase EFL student teachers' efficiency of the information search process through applying the Big6 Model.

4-Encourage EFL student teachers to apply the Big6 Model to their multimodal writing.

5-Enhance the confidence level of EFL student teachers for integrating different technological tools in their writing.

\section{Program rationale:}

The program was based on the Big6 Model to develop EFL student teachers' multimodal writing skills. The model was used as a guiding framework to help students search for information required for the multimodal writing tasks. The Big6 Model consisted of six steps: task definition, information seeking strategies, information location and access, information use, synthesis, and evaluation. These steps developed students' ability to plan for the information search, synthesize large amount of available information, and use technology to integrate linguistic, visual, and spatial items to produce multimodal texts.

To produce a multimodal text, students integrated at least a mode in the written text, a mode could be an image, audio, animation, or video. Students expressed their ideas using texts, fonts, colors, and other modes to overcome any weakness in their verbal expression. Multimodal writing bridged the gap between students' academic writing and their multimodal writing through social networks. Students produced digital multimodal texts everywhere using their mobile phones and the suggested program tried to introduce multimodal writing in the formal learning context.

\section{Program Content}

The program depended on different sources on multimodal writing and the Big6 Model, references were cited in each session. The researcher selected some topics for the multimodal writing tasks and students were asked to select topics of their interests. The topics selected were related to students' future careers, such as reciprocal teaching and dynamic assessment, see Appendix D.

\section{Program framework}

The experimental group received ten sessions based on the Big 6 Model. Each session lasted for three hours, the first hour of each session was dedicated to the researcher's explanation and the remaining two hours were for students' practice. The first session was an 
orientation session, students became aware of the Big 6 Model, its importance, and how to apply it on writing. Then, students received six sessions, each session covered a main multimodal writing skill and its subskills. Students practiced the application of the Big 6 Model to achieve such skills. Then, the scoring rubric was introduced to the students to get a general overview of how the multimodal texts were scored. They were offered two guided practice sessions where they produced multimodal texts of their interests. Both peer assessment and self- assessment were used to score students' texts (Appendix D).

\section{Reflection Reports}

After post testing, students were asked to write reflection reports describing their experience. They described how they benefited from the Big6 Model in their search for information and their multimodal text writing. They also described how multimodal writing developed their writing style to cope with the multimodal world where they lived (Appendix F). The following is an example of a student's reflection report:

When I search the Internet, I find large amount of search results. Sometimes more than a million results appear, and I feel anxiety. I used to open the results of the first page and neglect any further navigation. I feel that I can do more, and I need guidance to organize the information search process. The Big6 Model offers me organized steps to be followed. I enjoy using the model in writing as its steps align with the writing processes. Writing multimodal texts increases my confidence level since I feel that I can integrate different technological tools in my future career.

\section{Procedures}

The control and experimental groups were administered the multimodal writing test on October 2, 2019. The experimental group received ten sessions based on the Big6 Model. Students became aware of the model and applied it on each multimodal writing skill. Students assessed their texts and their colleagues' texts using the multimodal scoring rubrics. The control and experimental groups were administered the multimodal writing test on December 5,2019. The experimental group students were asked to write reflection reports on their experiences during the ten sessions. Data were analyzed using statistical methods.

\section{Data Analysis}

Data analysis was conducted using the Statistical Package for Social Science (SPSS), Version 16. Both descriptive statistics (means and standard deviations) and inferential statistics t-test were used in data analysis. The Independent-Samples t test was used to calculate the differences between the mean scores of the control and experimental groups in the Multimodal Writing Skill Test. Then, the calculated " $t$ " values were compared to the tabulated one (3.390). The alternative hypothesis was accepted as the calculated " $t$ " value (12.0850) was higher than the tabulated one.

\section{Results}

In this section, results are presented in terms of the research hypothesis. 


\section{Research Hypothesis}

There was a statistically significant difference between the mean scores of the control and experimental groups at $(\alpha \leq 0.01)$ level in the overall multimodal writing skills on the post administration of the multimodal writing test in favor of the experimental group.

The " $\mathrm{t}$ " values for multimodal writing skills were presented in the following table:

\section{Table 1}

t Values for Multimodal Writing Skills on the Post Administration of Multimodal Writing Test

\begin{tabular}{|c|c|c|c|c|c|c|c|c|}
\hline Skills & Group & $\mathbf{N}$ & Mean & $\begin{array}{l}\text { Std. } \\
\text { Deviation }\end{array}$ & Df & t-Value & Sig. & Result \\
\hline \multirow{2}{*}{$\begin{array}{l}\text { Accurate use of } \\
\text { Visuals }\end{array}$} & Control & 50 & 1.680 & 0.471 & \multirow{2}{*}{98} & \multirow{2}{*}{10.217} & \multirow{2}{*}{0.00} & \multirow{2}{*}{$\begin{array}{l}\text { Significant at } \\
\text { the } 0.01\end{array}$} \\
\hline & Experimental & 50 & 3.420 & 1.108 & & & & \\
\hline \multirow{2}{*}{$\begin{array}{l}\text { Consistent use } \\
\text { of different } \\
\text { Fonts \& Colors }\end{array}$} & Control & 50 & 1.760 & 0.517 & \multirow{2}{*}{98} & \multirow{2}{*}{10.474} & \multirow{2}{*}{0.00} & \multirow{2}{*}{$\begin{array}{l}\text { Significant a } \\
\text { the } 0.01\end{array}$} \\
\hline & Experimental & 50 & 3.500 & 1.055 & & & & \\
\hline \multirow{2}{*}{$\begin{array}{l}\text { Appropriate use } \\
\text { of Formatting \& } \\
\text { Layout }\end{array}$} & Control & 50 & 2.300 & 0.580 & \multirow{2}{*}{98} & \multirow{2}{*}{8.661} & \multirow{2}{*}{0.00} & \multirow{2}{*}{$\begin{array}{l}\text { Significant at } \\
\text { the } 0.01\end{array}$} \\
\hline & Experimental & 50 & 3.760 & 1.041 & & & & \\
\hline \multirow{2}{*}{$\begin{array}{l}\text { Comprehensive } \\
\text { content } \\
\text { development }\end{array}$} & Control & 50 & 2.480 & 0.707 & \multirow{2}{*}{98} & \multirow{2}{*}{7.962} & \multirow{2}{*}{0.00} & \multirow{2}{*}{$\begin{array}{l}\text { Significant at } \\
\text { the } 0.01\end{array}$} \\
\hline & Experimental & 50 & 3.640 & 0.749 & & & & \\
\hline \multirow{2}{*}{$\begin{array}{l}\text { Accurate } \\
\text { reference } \\
\text { citation }\end{array}$} & Control & 50 & 1.320 & 0.471 & \multirow{2}{*}{98} & \multirow{2}{*}{12.463} & \multirow{2}{*}{0.00} & \multirow{2}{*}{$\begin{array}{l}\text { Significant at } \\
\text { the } 0.01\end{array}$} \\
\hline & Experimental & 50 & 3.780 & 1.314 & & & & \\
\hline \multirow{2}{*}{$\begin{array}{l}\text { Attractive } \\
\text { multimodal text } \\
\text { production }\end{array}$} & Control & 50 & 1.460 & 0.706 & \multirow{2}{*}{98} & \multirow{2}{*}{9.940} & \multirow{2}{*}{0.00} & \multirow{2}{*}{$\begin{array}{l}\text { Significant at } \\
\text { the } 0.01\end{array}$} \\
\hline & Experimental & 50 & 3.340 & 1.136 & & & & \\
\hline \multirow{2}{*}{ Total Mark } & Control & 50 & 11.000 & 2.204 & \multirow{2}{*}{98} & \multirow{2}{*}{12.085} & \multirow{2}{*}{0.00} & \multirow{2}{*}{$\begin{array}{l}\text { Significant a } \\
\text { the } 0.01\end{array}$} \\
\hline & Experimental & 50 & 21.440 & 5.697 & & & & \\
\hline
\end{tabular}


The calculated " $t$ " values of the six main multimodal writing skills and the overall multimodal writing skills were higher than the tabulated one (3.390), thus the hypothesis was accepted.

Eta square $\left(\boldsymbol{\eta}^{\mathbf{2}}\right)$ and Cohen's $(\boldsymbol{d})$ were calculated using " $t$ " value for the differences between means, and interpreted according to the reference table:

\section{Table 2}

Effect Size Reference Table

\begin{tabular}{|c|c|c|c|c|c|c|}
\hline \multirow[b]{2}{*}{ Coefficient } & \multicolumn{6}{|l|}{ Effect Size } \\
\hline & Trivial & Small & Medium & Large & $\begin{array}{l}\text { Very } \\
\text { Large }\end{array}$ & Huge \\
\hline d & $\begin{array}{l}\text { Less Than } \\
0.20\end{array}$ & $\begin{array}{l}0.20 \\
0.49\end{array}$ & $0.50-0.79$ & $\begin{array}{l}0.80 \\
1.09\end{array}$ & $\begin{array}{ll}- & 1.10 \\
& 1.49\end{array}$ & $\begin{array}{ll}- & 1.50 \\
& \text { Or More }\end{array}$ \\
\hline$(\eta 2)$ & $\begin{array}{l}\text { Less Than } \\
0.010\end{array}$ & $\begin{array}{l}0.010 \\
0.058\end{array}$ & $\begin{array}{r}0.059 \\
0.137\end{array}$ & $\begin{array}{l}0.138 \\
0.231\end{array}$ & $\begin{array}{l}0.232 \\
0.359\end{array}$ & $\begin{array}{ll}- & 0.360 \\
& \text { Or More }\end{array}$ \\
\hline
\end{tabular}

\section{Table 3}

The Effect Size for the Big6 Model on EFL Multimodal Writing Skills

\begin{tabular}{|llllll|}
\hline \multirow{2}{*}{$\begin{array}{l}\text { Degrees of } \\
\text { Freedom }(\mathbf{d f})\end{array}$} & $\mathbf{t}$ - Value & & \multicolumn{2}{l}{ Cohen's d } & \multicolumn{2}{l|}{ Eta Squared $(\eta 2)$} \\
\cline { 3 - 6 } & & Value & Effect Size & Value & $\begin{array}{l}\text { Effect } \\
\text { Size }\end{array}$ \\
\hline 49 & 12.918 & 2.24 & Huge & 0.773 & Huge \\
\hline
\end{tabular}

The values of both Cohen's d and Eta Square $(\eta 2)$ were huge according to the reference table. Thus, the Big6 Model had a huge effect size on EFL student teachers' multimodal writing skills.

\section{Discussion of Findings}

Statistical analysis of the data obtained revealed the effectiveness of the Big 6 model in developing multimodal writing skills for third year EFL student teachers at a Faculty of Education. The effect size value for the Big 6 model $(d=2.24)$ was huge according to the effect size reference table. Also, the calculated " $t$ " value for every main multimodal writing skill was higher than the tabulated " $t$ " value (3.390). The most developed skills were accurate reference citation (12.463), consistent use of different fonts and colors (10.474), and accurate use of visuals (10.217).

The highest score of the accurate reference citation skill was due to students' awareness of the importance of this skill as an essential component of research in any subject area, as 
revealed in their reflection reports. Also, the third step of the Big6 model, location and access, was often guided by the quality and relevance of the sources and students gathered the details needed for citing the sources. Further, the fourth step of the model, use of information, depended on the correct use of information; Students avoided copying information, and they paraphrased or summarized ideas before citing the sources.

The high scores obtained in the skills of consistent use of different fonts and colors and accurate use of visuals were attributed to the characteristics of the digital world. Students lived in a visual world where they usually dealt with photos, images, and illustrations; thus, they were interested in applying the criteria of image size and position in their writing. Furthermore, students enjoyed using the video cutter to offer short chunks of information in their multimodal texts. They enjoyed the color wheel and how to contrast colors in addition to communicating different messages according to the fonts selected.

As revealed in the reflection reports of the experimental group, students enjoyed using the Big6 Model in their search process. They organized their search according to the steps of the model to be able to synthesize and judge the located information. They stated that the model enabled them to recover the feeling of lost and confusion among the large amount of data available. Besides, they enjoyed integrating the linguistic, visual, and spatial writing skills in their multimodal texts. They felt confident to produce content to be published on the Internet.

Students also integrated visuals and videos to illustrate their ideas, besides using different online tools: Creately, bubble.us, and video cutter. They differentiated between the format and layout of the text and identified their various options. They maintained that the Big6 Model enabled them to produce attractive multimodal texts. They integrated visual, linguistic, and spatial modals in their texts and used the scoring rubrics as a tool for developing their final multimodal text in addition to improving their learning processes.

\section{Conclusions}

The results reported in this research coincided with those of Jiang (2018) who concluded that a digital multimodal composing program changed university students from being examoriented into being EFL multimodal writers. The results were also similar to those of Lee (2014) who emphasized that multimodal writing tasks enhanced university students' motivation and confidence. Further, the findings were in line with those of Dzekoe(2013) who asserted the effect of computer-based multimodal writing activities in improving the quality of university students' ESL writing. In addition, the research results affirmed those of Ulu et al. (2017) who stated that multimodal literacy of pre-service teachers increased their perception of self-efficacy. Finally, the findings were similar to those of Hafner and Ho(2020) who revealed that a process- based model motivates university students in a L2 writing course.

\section{Recommendations and Suggestions for Further Research:}

-Assessing the impact of the Big6 Model on students' EFL learning motivation. 
-Examining the effect of the Big6 Model on secondary stage students' achievement in EFL.

-Examining the effect of multimodal writing on student teachers' attitudes towards online learning.

-Investigating teachers' perceptions towards integrating multimodal writing tasks in EFL teaching.

\section{References}

Adami, E.(2016). Multimodality. In O. Garcìa, N. Flores and M. Spotti (Eds.), Oxford Handbook of Language and Society (pp. 1-23). Oxford: Oxford

University Press.

Aggarwal, D. \& Sarman.(October, 2017). Understanding information literacy: A view from its models and standards. International Journal of Advance Research in Science and Engineering, 60(10), 1917-1927

Albers, P., \& Sanders, J. (2010). Literacies, the arts, and multimodality. Urbana, IL: National Council of Teachers of English.

Aydın, Z., \& Y1ldı, S. (2014). Using wikis to promote collaborative EFL writing. Language Learning \& Technology, 18(1), 160-180.

Bailey, N. (2012). The importance of a new literacies stance in teaching English language arts. In S. M. Miller \& M. B. McVee (Eds.), Multimodal composing in classrooms: Learning and teaching for the digital world (pp. 44-62). New York, NY: Routledge.

Beal, C. R., \& Stevens, R. H. (2011). Improving students' problem solving in a web-based chemistry simulation through embedded metacognitive messages. Technology, Instrumentation, Cognition and Learning, 8(3), 255-271.

Bezemer, J., \& Kress, G. (2008). Writing in multimodal texts: A social semiotic account of designs for learning. Written Communication, 25(2), 166-195.

https://doi.org/10.1177/0741088307313177

Brand-Gruwel, S., Wopereis, I., Walraven, A.( 2009). A descriptive model of information problem-solving while using Internet. Computers \& Education 53, (4),1207-1217.

Chiou, C., Hwang, G., and Tseng, J.(2009). An auto-scoring mechanism for evaluating problem-solving ability in a web-based learning environment. Computers \& Education, 53 , 261-272. http://doi:10.1016/j.compedu.2009.02.006

Cleary, M.. (2013). Flowing and freestyling: Learning from adult students about process knowledge transfer. College Composition and Communication, 64(4), 661-687. 
Cornford, I. R. (2005). Cognitive and metacognitive strategies as a basis for effective lifelong learning: how far have we progressed? In Proceedings of the AARE Annual Conference (pp. 1-15). Melbourne, Australia: Australian Association for Research in Education.

DePalma, M. \& Alexander, K. (2015). A bag full of snakes: Negotiating the challenges of multimodal composition. Computers and Composition, 37, 182-200

Dzekoe, R.(2013). Facilitating revision in the English as a second language (ESL) composition classroom through computer-based multimodal composing activities: A case study of composing practices of ESL students (Unpublished PhD. Dissertation). USA: Iowa State University.

Eisenberg, M. (2008). Information literacy: Essential skills for the information age. Journal of Library \& Information Technology, 28(2), 39-47.

Escamilla, K., Hopewell, S., Butvilofsky, S., Sparrow, W., Soltero-Gonzalez, L., RuizFigueroa,O., \& Escamilla, M. (2014). Biliteracy from the Start: Literacy squared in action. Philadelphia: Caslon Publishing.

Fjørtoft, H.(2020). Multimodal digital classroom assessments.Computers \& Education, 152,1-11 https://doi.org/10.1016/j.compedu.2020.103892

Foo,S., Majid,S., Mokhtar, I., Zhang, X., Chang, Y., Luyt, B.\& Theng,Y.(2014). Information literacy skills of secondary school students in Singapore. Aslib Journal of Information Management,66(1), 54-76 DOI 10.1108/AJIM-08-2012-0066

Ganapathy,M. \& Seetharam,S.(2016). The effects of using multimodal approaches in meaning-making of 21 st century literacy texts among ESL students in a private school in Malaysia . Advances in Language and Literary Studies, 7(2),143-155

Gee, J. (2014). Foreword. In F. Serafini (Ed.). Reading the visual: An introduction to teaching multimodal literacy. New York: Teachers College Press.

Hafner, C. \& Ho, W.(2020). Assessing digital multimodal composing in second language writing: Towards a process-based model. Journal of Second Language Writing , 47,1-14. https://doi.org/10.1016/j.jslw.2020.100710

Hassett,D., \& Curwood , J.(2009).Theories and practices of multimodal education: The instructional dynamics of picture books and primary classrooms. The Reading Teacher, 63(4), 270-282. http://doi:10.1598/RT.63.4.2

Huang ,C.\& Archer ,A.(2017). 'Academic literacies' as moving beyond writing: Investigating multimodal approaches to academic argument. London Review of Education,15(1), 6372.https://doi.org/10.18546/LRE.15.1.06

Hung,H., Chiu ,Y.,\& Yeh, H.(2013). Multimodal assessment of and for learning: A theorydriven design rubric. British Journal of Educational Technology,44(3),400409.http://dx.doi.org/10.1111/j.1467-8535.2012.01337.x 
International Society for Technology in Education (ISTE). (2016). ISTE standards for students. Washington, DC. Retrieved May 5,2019 from

https://www.iste.org/standards?utm_term=iste\%20standards\&utm_campaign=Brand+Searche $\underline{\text { s\&utm_medium }=p p c \& u t m \_s o u r c e=a d w o r d s \& h s a \_g r p=61360599075 \& h s a \_m t=p \& h s a \_t g t=k}$ wd300823742300\&hsa_acc $=3340209094 \&$ hsa_cam $=1573266230 \&$ hsa_kw $=$ iste\%20standard

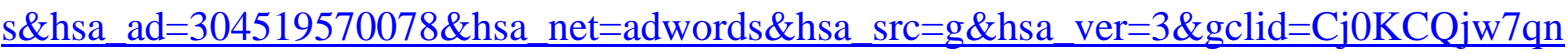
1BRDqARIsAKMbHDaR-yvLO4s5qQbecU1hsyMcn5Q1NFrmSYTt4vBm4gebQ1SjAOOiSwaAu5oEALw_wcB

Jewitt, C. (2014). An introduction to multimodality. In C. Jewitt (Ed.), The Routledge handbook of multimodal analysis(pp.1-27), 2nd ed. London: Routledge.

Jiang, J.(2018). Digital multimodal composing and investment change in learners'writing in English as a foreign language. Journal of Second Language Writing, 40, 60-72.

Karadeniz, Ş.(2014). Integrating Big6 Information Literacy Skills in Project Based Learning: A Case Study in Higher Education.

\section{https://www.researchgate.net/publication/260505710}

Kicken, W., Brand-Gruwel, S., \& Van Merriënboer, J. J. G. (2008). Scaffolding advice on task selection: A safe path toward self-directed learning in on-demand education. Journal of Vocational Education and Training, 60(3), 223- 239.

Kitalong,K.\& Miner,R.(2017). Multimodal composition pedagogy designed to enhance authors' personal agency: Lessons from non-academic and academic composing environments. Computers and Composition, 46, 39-55.

Kress, G. (2003). Literacy in the new media age. London: Routledge.

Kress, G. and van Leeuwen, T. (2001). Multimodal discourse: The modes and media of contemporary communication. London: Arnold.

Kumar, M., Natarajan, U., \& Shankar, S. (2005). Information literacy: A key competency to students' learning. Malaysian Online Journal of Instructional Technology, 2(2), 50-60.

Lee. H.(2014). Using an arts-integrated multimodal approach to promote English learning: A case study of two Taiwanese Junior college students. English Teaching: Practice and Critique, 13(2),55-75

Loo, A. \& Chung, C.(2006). A model for information literacy course development: a liberal arts university perspective. Library Review,55(4),249-258. Doi: 10.1108/00242530610660799

Marino, J. (January, 2019). The Big6 Becomes the Big6.org. https://thebig6.org/ McGrail , E. and Behizadeh, N.(2017). Writing K-12 multimodal assessment and interactive audiences: An exploratory analysis of existing frameworks. Assessing Writing, 31,24-38. 
McConnell, P.(2014). Get the Picture: Teaching with multimodal texts. ELTWorldOnline.com, 6,1-21.

Mendoza,J., Pamatmat,F., Daran,A., Pamin,C.(2020). Employing Big6 process for the development of information literacy among college students. International Journal of Scientific \& Technology Research, 9(3),901-906.

Miller-Cochran, S.(2017). Understanding multimodal composing in an L2 writing context. Journal of Second Language Writing, 38, 88-89.

National Authority for Quality Assurance and Accreditation of Education (NAQAEE).(2013).National Academic Rubrics for the Education Sector Faculties. Arab Republic of Egypt. Retrieved on May 2, 2019 from https://naqaae.eg/wp- content/uploads/2014/PDF/29.pdf

Nelson, M. (2006). Mode, meaning, and synesthesia in multimedia L2 writing. Language Learning \& Technology, 10(2), 56-76.

Nesset, V.(2014). New Directions in Children's and Adolescents' Information Behavior Research. Library and Information Science, 10, 39-66. doi:10.1108/S1876056220140000010017

Palincsar, A. ( 1986). Metacognitive strategy instruction. Exceptional Children 53, ( 2), 118 24.

Probert, E., (2009). Information literacy skills: teacher understandings and practice. Computers \& Education 53, 24-33.

Pórarinsdóttir, P. \& Pálsdóttir,A. (2011). Information Literacy. Learning theories and assessment. In Ása Guðný Ásgeirsdóttir, Helga Björnsdóttir \& Helga Ólafs (Eds), Pjóðarspegillinn. Rannsóknir í félagsvísindum XI. Félags- og mannvísinda-deild (pp. 630639). Reykjavík: Félagsvísindastofnun Háskóla Íslands .Retrieved 12 from http://skemman.is/en/stream/get/1946/10261/ 25581/3/ Felags ogmannv_deild.pdf

Raes, A., Schellens, T., De Wever, B., \& Vanderhoven, E. (2012). Scaffolding information problem solving in web-based collaborative inquiry learning. Computers \& Education, 59, 82-94. http://dx.doi.org/10.1016/j.compedu.2011.11.010

Ryu,J.\& Boggs,G.(2016).Teachers' Perceptions about teaching multimodal composition: The Case study of Korean English teachers at secondary schools. English Language Teaching, 9( 6), 52-60.

Scanlon, M.(2015).The work of comics collaborations: Considerations of multimodal composition for writing scholarship and pedagogy. Composition Studies, 43(1 ),105130.https://eric.ed.gov/?id=EJ1062057 
Shanahan, L. (2012). Lessons in multimodal composition from a fifth-grade classroom. In. S. Miller \& M. McVee (Eds.), Multimodal composing in classrooms: Learning and teaching for the digital world (pp. 97-113). New York: Routledge.

Shepherd ,R.(2018).Digital writing, multimodality, and learning transfer: Crafting connections between composition and online composing. Computers and Composition, 48 , 103-114.

Shoeb , Z.(2020).Evidence of improved students' perceptions towards online research: pre and post assessment study of information literacy and research support. Global Knowledge, Memory and Communication.16ps. doi 10.1108/GKMC-04-2020-0054

Swapna, G.\& Biradar, B.(2017). Information literacy model for higher education institutions in India. International Journal of Digital Library Services, 7 (3),31- 50. http://www.ijodls.in/uploads/3/6/0/3/3603729/4ijodls3717.pdf

Takayoshi, P., \& Selfe, C. (2007). Thinking about multimodality. In C. Selfe \& G. Hawisher (Eds.), Multimodal composition resources for teachers: new dimensions in computers and composition(pp.1-12). New Jersey: Hampton Press.

Tan, S., O'Halloran, K., \& Wignell, P. (2016). Multimodal research: Addressing the complexity of multimodal environments and the challenges for CALL. ReCALL, 28(3), 253273. https://doi.org/10.1017/S0958344016000124

Tsai, M., Liang, J., Hou, H. and Tsai, C.(2012). University students' online information searching strategies in different search contexts. Australasian Journal of Educational Technology, 28(5), 881-895

Ulu, H., Avşar-Tuncay, A., and Baş, O.(2017). The relationship between multimodal literacy of pre-service teachers and their perception of self-efficacy in critical reading. Journal of Education and Training Studies, 5(12),85-91.

Vandergriff, I. (2016). Second-language discourse in the digital world: Linguistic and social practices in and beyond the networked classroom. Amsterdam: John Benjamins.

Vincent, J. (2006). Children writing: Multimodality and assessment in the writing classroom. Literacy, 40(1), 51-57.

Wiseman, A., Pendleton, M., Christiansen, C.,\& Nesheim, N.(2017).A case study of struggle and success: Profiling a third grader's reading and writing in a multimodal curriculum. Journal of Language and Literacy Education, 13(1), 55-69.

Wolf, S.(2003) The Big Six Information Skills as a Metacognitive Scaffold: A Case Study. School Library Media Research, Vol 6, 2003. ISSN: 1523-4320.

Yi ,Y.(2017).Establishing multimodal literacy research in the field of L2 writing: Let's move the field forward. Journal of Second Language Writing, 38, 90-91. www.elsevier.com/locate/jslw 
Yeh, H., Heng,L., Tseng, S.(2020). Exploring the impact of video making on students' writing skills. Journal of Research on Technology in Education. 12pshttps://doi.org/10.1080/15391523.2020.1795955

Zhang, Y,(2019). Preparing teachers to work with English learners: A multimodal vocabulary mini-lesson project. TESOL Journal. 2020;00:e569. 21ps https://doi.org/10.1002/tesj.569

Zhou, M. \& Lam,K. (2019). Metacognitive scaffolding for online information search in K-12 and higher education settings: a systematic review. Education Tech Research,67,13531384.https://doi.org/10.1007/s11423-019-09646-7 


\title{
فاعلية نموذج Big6 فى تنمية مهارات الكتابة متعددة الوسائط فى اللغة الإنجليزية كلغة أجنبية لدى الطلاب المعلمين
}

\author{
هاجر التونسي \\ أستاذ مساعد قسم المناهج و طرق التدريس، كلية التربية، جامعة حلوان
}

المستخلص

استهدف البحث الحالى تحديد فاعلية برنامج مقترح قائم على نموذج Big6 فى تنمية مهار ات الكتابة

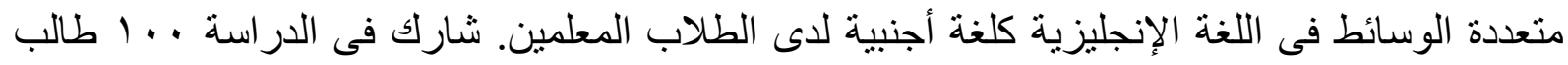

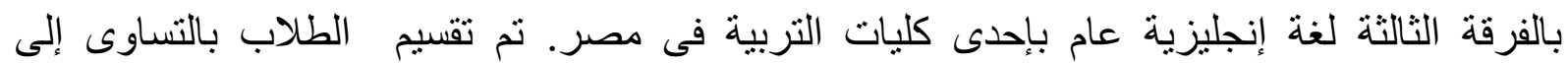

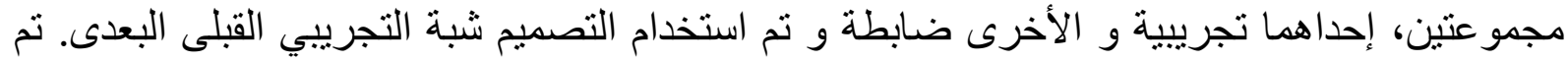

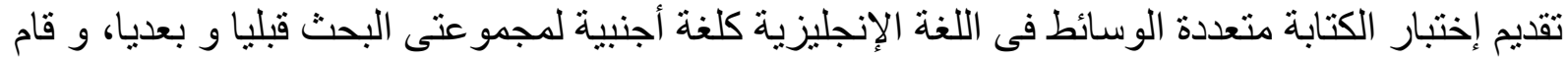
إثنين من المقيمين بتصحيح الإختبار فى ضوء معيار التقييم الذى اقترحه الباحث. تم تقديم البرنامج

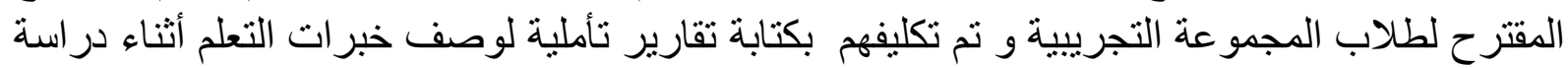
البرنامج. أوضحت نتائج التحليل الإحصائى لدرجات الطلاب فى التقديم البعدى لإختبار مهار ات الكتابة

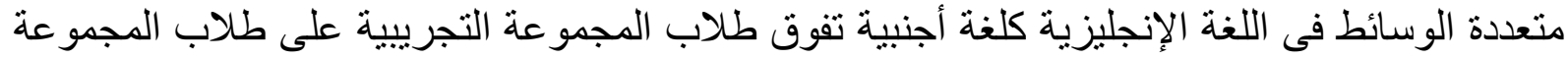
الضابطه و كان للبرنامج المقترح حجم أثر كبير (d=2.24) كما ساهم البرنامج المقترح فئ تنمية مهار ات البحث عن المعلومات و مهار ات الكتابة متعددة الوسائط للى طلاب المجموعة التجريبية.

الكلمات المفتاحيه : نموذج Big6، مهار ات الكتابة متعددة الوسائط، الطلاب المعلمين

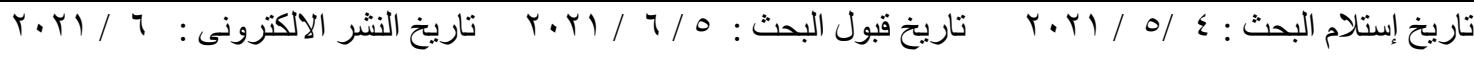

